\title{
EVIDENSBASERET POLITIKUDVIKLING
}

\author{
Brudflader mellem forskning og bureaukrati
}

\author{
NINA HOLM VOHNSEN
}

I USA og de europæiske velfærdsstater har det gennem længere tid været en central ambition for regeringerne at basere politiske beslutninger på grundig research (Bason 2010; Cartwright et al. 2009; Mulgan 2009; Nilsson et al. 2008). Promoveret under betegnelser som „evidence-based policy-making“, „,good analysis“ og „better governance“ (Nilsson et al. 2008) tager denne aspiration sit afsæt i det styringsparadigme, som refereres til som new public management (Hartley 2005) - og dermed i bestræbelsen på at skabe en offentlig sektor, som på én gang er effektiv og økonomisk rentabel (se også Rod 2010). Hvor samfundsvidenskabernes direkte indflydelse på offentlig politikudvikling mindst kan spores tilbage til det tidlige 1900-tal (Miller \& Rose 2008:26ff.), blev bestræbelsen på at udvikle egentlig evidensbaseret politik først for alvor - i Europa - sat i gang med valget af New Labour i Storbritannien i 1997. Med USA som referencepunkt spredte ambitionen om en evidensbaseret praksis sig herefter til resten af de nord- og vesteuropæiske lande i løbet af det følgende årti (Nilsson et al. 2008).

Den helt centrale tanke i det evidensbaserede paradigme er, at frem for at lade sig lede af ideologiske overbevisninger eller rent forestillede løsninger på komplekse samfundsmæssige problemstillinger, bør lovgivning og anden politik baseres på et solidt vidensgrundlag fremskaffet gennem research eller ved anvendelse af komplekse effektvurderingsredskaber (appraisal tools). Alt dette i en bestræbelse på at fastslå, hvilken type indsats der faktisk vil afstedkomme en ønsket samfundsændring. Selv om denne ambition synes fornuftig, har de artikler og rapporter, som har analyseret brugen af evidens, påpeget en række problematiske forhold (fx Boden \& Epstein 2006; Cartwright et al. 2009; Elliott \& Popay 2000; House of Commons 2006; Nilsson et al. 2008; Whitty 2006; Rod 2010; Vohnsen 2011, 2013). Nogle advarer om, at begrebet „evidensbaseret“ bruges alt for skødesløst og ofte i tilfælde, hvor evidensen ikke har bidraget direkte til policyudviklingen, men snarere er blevet nøje udvalgt og mobiliseret, efter at 
en politisk kurs allerede er blevet udstukket (House of Commons 2006; Nilsson et al. 2008). Andre advarer om, at politik og forskning er svært - om ikke umuligt - at forene (fx Boden \& Epstein 2006; Vohnsen 2013; Whitty 2006).

I denne artikel vil jeg undersøge, hvori gnidningspunkterne mellem politikudvikling og forskningspraksis består. Jeg vil undersøge et konkret forsøg på at lave evidensbaseret politik på det arbejdsmarkedspolitiske område mellem 2007 og 2010. Hovedfokus er på embedsværket i Beskæftigelsesministeriet og dets arbejde hen imod en trepartsaftale om sygefravær som formuleret i ,Konklusionspapir om handlingsplanen om sygefravær" (vedtaget i efteråret 2008), og på et af dens centrale forslag - forslaget om at gennemføre et randomiseret, kontrolleret forsøg - som slutteligt blev implementeret i 16 kommuner i første halvdel af 2009. Hvad denne analyse særligt ønsker at fremhæve, er, at den umiddelbart fornuftige evidensbaserede ambition udfordrer embedsmandsarbejdet $i$ en grad, der ikke synes forenelig med dets ekspertise. En slagside ved dette er, at når embedsmændene går til den evidensbaserede politikudvikling, som de ville gå til ethvert andet stykke policyarbejde, kommer det til at fremstå, ikke som godt embedsmandsarbejde, men som illegitimt og manipulerende.

\section{Kritikken af den „evidensbaserede“ politikudvikling}

Bestræbelserne på at udvikle evidensbaseret politik i Europa begyndte for alvor med valget af New Labour i Storbritannien i maj 1997 (Whitty 2006). Med USA som forbillede opfordrede den britiske premierminister Tony Blair sin centralregering og dermed de tilknyttede administrationer til at gøre bedre og mere systematisk brug af analyse og ,appraisal tools“ $\mathrm{i}$ deres arbejde med at udvikle politikker og lovgivning (Nilsson et al. 2008). Den britiske regering ønskede at finde frem til det, „som virkede“, på de forskellige politikområder. Det medførte en vækst i finansieringen af anvendte forskningsprogrammer og forskningscentre (Whitty 2006:163). Ambitionen var hermed på den ene side at tilskynde til en type forskning, som var direkte relevant for politikudviklingen og dennes praktiske udmøntning, og på den anden side at sammenfatte eksisterende forskning til gavn for politikudviklerne (op.cit.164). Forholdet mellem ambitionen om at arbejde evidensbaseret og den faktiske politik, som blev vedtaget, blev fra starten fulgt nøje fra det britiske forskningsmiljø. De efterfølgende analyser af forholdet havde det til fælles, at de alle identificerer et mismatch mellem, hvordan forskning hævdes at blive brugt inden for det evidensbaserede paradigme, og den faktiske måde, den blev bragt til anvendelse på i konkrete sager.

I et tidligt studie analyserede Heather Elliott og Jennie Popay (2000) brugen af forskning i det britiske sundhedsvæsen. De konkluderede, at når politiske 
beslutninger skulle træffes og retninger udstikkes, var forskning blot én af en lang række informationskilder, som beslutningstagerne trak på. Andre væsentlige kilder var budgetrammer, organisatoriske målsætninger samt personlige erfaringer (op.cit.465ff.). I 2006, da det britiske underhus publicerede en rapport om regeringens brug af videnskabelig rådgivning og evidens i relation til politikudvikling, var rapportens primære konklusion, at regeringen burde nedtone det evidensbaserede „mantra“ og mere åbent anerkende de store huller, der ofte var i dens evidensgrundlag (House of Commons 2006:3). Mens komiteen bag rapporten gav sin fulde støtte til bestræbelserne på at integrere den videnskabelige tilgang i politikudviklingsarbejdet, understregede den sin bekymring over tendensen til at anvende ordet ,evidensbaseret“ for letsindigt og i tilfælde, hvor det ofte var helt andre bevæggrunde, der drev politikker frem, ,... det være sig politiske hensyn, $[\ldots]$ moralske standpunkter $[. .$.$] eller vigtig respons på omstændigheder$ eller politikområder, hvor der er sparsom eller ingen evidens at trække på“ (House of Commons 2006:164, min oversættelse, NHV).

Komiteen bag rapporten advarede i særlig grad imod to relaterede praksisser, den havde dokumenteret, dels en særdeles selektiv udvælgelse af evidensgrundlag til støtte for eksisterende politik, dels bestilling af research med det formål for øje at retfærdiggøre allerede planlagte indsatser. Disse praksisser blev i rapporten omtalt som „politikbaseret evidensudvikling“ i modsætning til evidensbaseret politikudvikling (op.cit.164, min oversættelse, NHV). Denne vending havde de hentet fra Rebecca Boden og Debbie Epsteins kritiske diskussion af relationen mellem det britiske forskningsmiljø og dét, de refererede til som „,neoliberale sandhedsregimer“ (Boden \& Epstein 2006:223, min oversættelse, NHV). Med „neoliberalt sandhedsregime“ henviser de til tendensen blandt vor tids regeringer til at anvende såkaldt „objektiv viden“ tilvejebragt via forskning eller research som primær kilde til at legitimere beslutninger (op.cit.233f.; se også Tynell 2014).

Med denne sprogbrug skriver Boden og Epstein sig ind i samme kritiske foucauldianske forskningstradition, som Peter Miller og Nikolas Rose repræsenterer. I deres klassiske artikel „Governing Economic Life“ (2008) undersøger Miller og Rose, hvordan samfundsvidenskaberne har haft indflydelse på regeringsstrategier op gennem det 20. århundrede. De viser, hvordan videnskabelig forskning siden de første årtier af 1900-tallet i stigende grad er blevet brugt til at retfærdiggøre indsatser og lovgivning af dem, som udvikler politik (op.cit.44f.), hvilket har muliggjort, at store reformer og indsatser kan fremstilles som politisk neutrale (for relaterede argumenter, se Ferguson 1994; Li 2007). Måns Nilsson og hans forskerhold (Nilsson et al. 2008) når en lignende konklusion i deres omfattende sammenligning af brug og manglende brug af forskning og komplekse effektvurderingsredskaber i en række europæiske regeringer og offentlige institutioner. Også de dokumenterer en tendens til primært at gøre brug af research, når der 
skal mobiliseres støtte til allerede planlagte indsatser og lovgivningsændringer. Både Nilsson og hans forskerhold (2008), Elliot og Popay (2000) og Whitty (2006) har haft analytisk gavn af den typologi, som Carol Weiss fremlagde for mere end 30 år siden på baggrund af sin analyse af de forskellige måder, hvorpå forskning kan få indflydelse på politiske beslutninger (Weiss 1979). Weiss opstillede syv modeller, som skal forstås som nedslag i et kontinuum af varierende praksis, der strækker sig fra dét, hun kaldte „problemløsningsmodellen“, hvor „research bidrager med empirisk evidens og konklusioner, som hjælper til at løse et politisk problem“ (Weiss 1979:427, min oversættelse, NHV), over „den interaktive model“", hvor research „blot er ét element i en kompliceret beslutningsproces, som også trækker på erfaring, politisk indsigt og pres, sociale teknologier, og dømmekraft“" (op.cit.428, min oversættelse, NHV), og videre til den ,politiske model“", hvor research håndplukkes som ,ammunition for den part, der finder dens konklusioner anvendelige“ (op.cit.429, min oversættelse, NHV).

Opsummerende kan man sige, at analytikerne af den evidensbaserede praksis i nutidig europæisk sammenhæng er enige om, at evidensbaseret politikudvikling er en illusion i det omfang, den præsenteres af regeringerne og deres administrationer i „problemløsningsudgaven“. Politikker og lovgivninger bliver, ifølge ovenstående praksisanalyser, simpelthen ikke til som resultat af omhyggelig og udtømmende forskningsgennemgang (research), som følge af egentlig forskning (som kontrollede forsøg) eller efter anvendelse af de komplekse beregningsmodeller (appraisal tools), som regeringerne og deres administrationer ellers hylder. I stedet synes praksis at korrespondere langt bedre med „den interaktive model", hvor forskning eller analyser blot udgør ét element blandt mange i beslutningsprocesserne forud for vedtagelse af politik, eller med „den politiske model", hvor forskning håndplukkes efter forgodtbefindende, som det fx dokumenteres i rapporten fra det Britiske Underhus (House of Commons 2006). Alligevel, trods bevis for det modsatte, er det fortsat ,problemløsningsmodellen“ for forskningsbrug, som hævdes at være anvendt, og som holdes frem som gylden standard af de nordeuropæiske regeringer (Elliott \& Popay 2000:462; Nilsson et al. 2008:337; Vohnsen 2011).

\section{Forskning og politikudvikling - brudflader mellem ekspertisefelter}

I det følgende vil jeg se nærmere på dette paradoks - at regeringerne og deres embedsværk vedbliver at hylde og efterstræbe en praksis, der i forskningsmiljøerne er bred enighed om, er illusorisk og umulig. Det vil jeg gøre ved at videreudvikle en idé, som blev fremsat af Geoff Whitty (2006), forhenværende præsident for British Educational Research Association. Ideen er enkel, nemlig at relationen 
mellem forskere og politikudviklere er kendetegnet ved gensidig mangel på forståelse eller decideret ved misforståelser. ${ }^{1}$ I al sin enkelhed giver denne idé os en mulighed for at forstå den aktuelle brug af evidens som resultat af en beslutningsproces, der er karakteriseret ved at bevæge sig langs brudfladerne mellem to fundamentalt forskelligt konstituerede discipliner (videnskab og politikudvikling), snarere end blot som resultat af manglende vilje eller endog manipulation. Hvor det allerede er blevet grundigt dokumenteret, at evidens sjældent, hvis nogensinde, bidrager direkte til politikudviklingen, er mit ærinde her at undersøge, hvordan dette sker: Hvordan går det altså til - ofte trods de bedste intentioner - at evidens ikke anvendes i politikudviklingen?

I min bestræbelse på at besvare dette spørgsmål vil jeg i det følgende beskrive tilblivelsen af et konkret stykke politik, „Handlingsplanen om sygefravær“, og dernæst definere og beskrive de brudflader, der er mellem forskningsmiljøerne og politikudviklingsmiljøerne, og hvor de altså, med Whittys ord, støder sammen i en række gensidige misforståelser. Disse misforståelser drejer sig om forskellen på akademisk og politisk tekstproduktion og om, hvad en policy faktisk er. Det drejer sig også om, hvilken status debat og kritik indtager i de to domæner, samt endelig om, hvad genstanden for det håndvcerk, embedsmænd og -kvinder udøver, er. I overensstemmelse med de danske embedsmænds og -kvinders sprogbrug vil jeg i det følgende anvende samlebetegnelsen ,policyudvikling“" om den udfærdigelse af handlingsplaner, lovtekster, projekter og strategiske retningslinjer, som udgør kernen i deres arbejde.

\section{Første brudflade: evidensbasering versus policyudvikling}

Da finansloven for 2009 skulle forhandles på plads i november 2008 indtog „Konklusionspapir om handlingsplanen om sygefravær“ (Beskæftigelsesministeriet 2008a) en helt central position. Aftalen skulle være et redskab til ikke bare at forhindre og forebygge permanent afgang fra arbejdsmarkedet for de langtidssygemeldte, men også til at reducere de offentlige ydelser til sygedagpenge og overførselsindkomster og dermed samlet set bidrage til at lukke et væsentligt hul i de offentlige budgetter (for detaljer, se Vohnsen 2011). Helt afgørende for at opnå dette mål var handlingsplanens forslag 32 ,Forsøg med forebyggende og afklarende tilbud“. Dette forsøg var et af de første eksempler på et kontrolleret forsøg udført af (og ikke på vegne af) en offentlig myndighed i Danmark og det endog på et felt udgjort af en kompleks blanding af arbejds- og helbredsrelaterede samt sundhedsorganisatoriske problemstillinger.

Handlingsplanens tilblivelse var usædvanlig. Det understregede Lea, en højtstående embedskvinde, fra Beskæftigelsesministeriets departement, da jeg 
interviewede hende om forsøgets og handlingsplanens forberedende stadier. Normalt, forklarede hun, bliver policy til på en af tre måder. Den ene måde er „strategisk policyarbejde“. Det er policy, som bliver udarbejdet på baggrund af et regeringsprogram ( $\mathrm{fx}$ at en nyvalgt regering erklærer sin intention om at nedbringe det samlede sygefravær med 20 procent før år 2015). Typisk vil der gå en forholdsmæssig lang udviklingsproces forud for dette arbejde. En anden måde, populært kaldet ,responspolitik“, er policy, som bliver udarbejdet som reaktion på kritik rejst i nyhedsmedierne eller i Folketinget (fx kan det dreje sig om utilsigtede bivirkninger ved eksisterende lovgivning, som vil lede til lovændringer) eller som respons på uforudsete begivenheder ( $\mathrm{fx}$ en finanskrise). Endelig, fortsatte Lea, kan den sidste form for policyarbejde, som embedsværket bedriver, beskrives som en slags proaktivt arbejde, hvor policy udarbejdes i en bestræbelse på at foregribe kritik, som rygtes at være undervejs fra de store interesseorganisationer (såsom Dansk Industri eller Kommunernes Landsforening, KL). De to sidste typer politikudvikling er kendetegnet dels ved deres uforudsigelighed og dels ved, at embedsværket har meget kort tid til rådighed til at udarbejde deres beslutningsoplæg. Det usædvanlige ved „Handlingsplanen om sygefravær“ var derfor, at udviklingsarbejdet blev sat i gang internt $i$ embedsværket på eget initiativ frem for efter anvisning eller ønske fra politikerne.

Det hele begyndte i Arbejdsmarkedsdirektoratet i efteråret 2007, huskede Lea, hvor analytikerne opdagede en atypisk udvikling i udgifterne til sygedagpenge. At udgifterne syntes at være „eksploderet“", er noget, man som embedsværk skal reagere på. Ikke så meget udgiftsstigningen i sig selv, understregede Lea, som det, den er udtryk for, nemlig en stigning i antallet af folk, der som følge af sygefravær står uden for den ,aktive arbejdsstyrke“" og modtager overførselsindkomster. Udviklingen blev først forelagt Lea, da hendes kollegaer i Arbejdsmarkedsdirektoratet sendte en analyserapport et trin op i det organisatoriske hierarki til departementet, specifikt til Leas kontor, som hører direkte under beskæftigelsesministeren. Denne første analyserapport var udarbejdet på baggrund af det statistiske materiale, som embedsværket havde til rådighed. Det, som primært havde fanget analytikernes opmærksomhed, var det faktum, at udviklingen i det ,langvarige sygefravær“" syntes at være hovedansvarlig for udgiftsstigningen. Det langvarige sygefravær var defineret som sygefravær af mere end otte ugers varighed. Otte uger var et vigtigt administrativt tidsrum, idet det var skæringspunktet for, hvornår kommunernes pligt til opfølgning i sagerne begyndte. Det så altså ud, som om en relativt lille gruppe personer - de langtidssygemeldte - var ansvarlige for hovedparten af det samlede danske sygefravær. Da departementschefen blev forelagt denne analyse, besluttede han at holde en række møder, hvor forskellige folk fra ministeriets styrelser og enheder blev inviteret til at diskutere udfordringerne i forhold til det langvarige sygefravær, sådan som de så det. 
Departementschefen fortalte mig sidenhen, at de havde stået i en lignende situation tilbage i 2003. Dengang, som i 2007, havde der været generel bekymring for arbejdsudbuddet, og tabet af arbejdskraft grundet sygefravær havde været alarmerende, idet det så ud til at stige støt. Dengang havde de set sig om efter internationale erfaringer på området og havde udfærdiget en indsats på baggrund af disse. Denne gang ønskede han at gå mere grundigt til værks. I sin tid som departementschef i Beskæftigelsesministeriet, fortalte han mig, havde det været en af hans helt centrale ambitioner at udvikle ministeriets analytiske kapacitet og grundlægge en vidensbaseret praksis i forhold til udviklingen af policy. Hans ideal var, at i det øjeblik, politikerne formulerede et ønske eller udstak en strategi, skulle de i embedsværket allerede have forudset, at dette ville blive et fokusområde og allerede have brugt tid på at undersøge forskellige scenarier og deres implikationer. Før i tiden, fortsatte han, blev de fleste politiske beslutninger truffet på meget spinkle vidensgrundlag og ud fra troen på, at dette eller hint ville virke. I modsætning til dette var hans ønske, at policy skulle baseres på grundige undersøgelser af, om indsatser virker eller ej, helst på baggrund af kontrollerede forsøg:

Hvis vi kan sige, at vi har undersøgt, at det eller det er den bedste måde at få folk tilbage i arbejde på, og hvis vi har - jeg havde nær sagt videnskabelig - men i det mindste klar dokumentation for, at det er den klogeste måde at gøre det på, jo mere vi kan gøre det, des bedre.

Efter det indledende møde, hvor ministeriets ansatte var blevet inviteret til at dele deres viden og erfaringer vedrørende det langvarige sygefravær, besluttede departementschefen sig for, at tiden var inde til at begynde en undersøgelse af, hvad der kunne gøres for at nedbringe sygefraværet. Lea, som kom til at stå i spidsen for den proces, der fulgte, fortalte mig, at deres input indtil da havde været begrænset til, hvad man vidste internt $\mathrm{i}$ administrationen. Nogle havde løbende kontakt med KL og havde i årenes løb oparbejdet en klar idé om, hvad kommunerne efterspurgte på sygedagpengeområdet, og hvad de anså for at være de største hindringer for hurtige raskmeldinger. Andre havde regelmæssig kontakt med både sygemeldte borgere og individuelle sagsbehandlere, som ringede ind til ministeriet for at klage eller stille spørgsmål om bestemte regler i den gældende lovgivning, som de fandt vanskelige eller uhensigtsmæssige. Dertil kom, at beskæftigelsesområdet var under konstant evaluering, og rundt om i ministeriets enkelte styrelser havde man et pænt antal sådanne rapporter. Det var nu Leas opgave at samle og oversætte al denne information til et antal udfordringer og tilhørende løsningsscenarier, som sidenhen skulle forelægges ministeren. Indtil da havde de endnu ikke involveret ministeren i deres planer. Hvad de havde foretaget sig, var simpelthen bare, 
sagde Lea, at yde ,almindelig god ministerbetjening“. De havde holdt øje med tingenes udvikling, og nu kunne de på baggrund af deres analysearbejde hjælpe ministeren ved at påpege uregelmæssigheder og fremlægge en række forslag til, hvad man kunne tænkes at gøre ved det. Men så skete der noget uforudset, som satte gevaldigt skub i beslutningsprocessen.

I oktober 2007 udskrev statsminister Anders Fogh Rasmussen folketingsvalg og fremlagde i november - efter genvalg - et regeringsprogram, hvoraf det fremgik, at en central målsætning for regeringen var en reduktion af sygefraværet på 20 procent før 2015. Umiddelbart efter valget kastede embedsværket sig derfor over arbejdet med at udfærdige et „bruttokatalog“ med udfordringer og løsninger, som beskæftigelsesministeren kunne tage med hjem på juleferie. Blandt de embedsmænd, som blev bedt om at bidrage til processen, var en af juristerne, Jytte, fra Arbejdsmarkedsstyrelsen. „Jeg havde en god aften der op til jul, “ huskede hun, „hvor jeg lige fik skrevet ti forslag over en kop te. Bare korte forslag, en siders penge eller sådan." Hvis det lyder som sjuskearbejde, så var det ikke nødvendigvis tilfældet. Hun kunne gøre det så hurtigt, forklarede hun, fordi hun havde arbejdet på feltet så længe. Inspirationen hentede hun primært fra den nyligt publicerede afbureaukratiseringsrapport fra konsulentfirmaet Deloitte og fra sit netværk i de øvrige skandinaviske landes centraladministrationer. Blandt de forslag, som Jytte tog fra afbureaukratiseringsrapporten, var et ønske fremsat af landets kommuner om at få mulighed for at henvise sygedagpengemodtagere til fysioterapi og psykolog samt at kunne tilbyde andre former for aktivitet, som kunne bidrage til, at folk hurtigere kunne vende tilbage til arbejdsmarkedet efter eller under langvarige sygdomsforløb.

Efter input fra beskæftigelsesministeren udviklede bruttokataloget sig i løbet af det næste halve år. Ministeren understregede over for sin administration vigtigheden af, at alle de store interesseorganisationer fra KL over Dansk Arbejdsgiverforening (DA) og Lægeforeningen (PLO) skulle kunne genfinde deres forslag $\mathrm{i}$ det endelige produkt. Han ønskede en indsats, fortalte Lea, som nød bred opbakning fra interessenterne på området. Sideløbende med finpudsningen og offentliggørelsen af den første analyserapport, ,Analyse af sygefraværet“ (Beskæftigelsesministeriet 2008b), kondenseredes bruttokataloget gradvist via ,Sygefravær en fælles udfordring“ (Regeringen 2008) i ,Konklusionspapir om handlingsplanen om sygefravær“" (Beskæftigelsesministeriet 2008a). Godt hjulpet på vej af det bestilte review „Viden om sygefravær“(Arbejdsmarkedsstyrelsen 2008) blev en central påstand, som flere af handlingsplanens forslag byggede på, snart promoveret og brugt i den offentlige debat, nemlig, at der var evidens for, at folk ville blive hurtigere raske, hvis de holdt sig aktive under sygdom. Mellem den aften i december 2007, hvor Jytte havde skrevet sine forslag over en kop te, og den 
formelle fremlæggelse af handlingsplanen i november 2008, havde hendes forslag om muligheden for at yde psykologhjælp og anden aktivitet udviklet sig til en storslået ambition om at føre evidensbaseret politik gennem et randomiseret, kontrolleret forsøg under ledelse af Arbejdsmarkedsstyrelsen. Handlingsplanen blev vedtaget ved trepartsforhandlingerne mellem arbejdsmarkedets parter i september 2008 og dernæst politisk vedtaget via finanslovsforhandlingerne i november.

Det, som bør stå klart efter ovenstående fortælling om oprindelsen til både det kontrollerede forsøg og „Handlingsplanen om sygefravær“, er, at en policy typisk helt fra udgangspunktet tjener en lang række forskelligartede formål. Som David Mosse $(2005,2007)$ gør opmærksom på, vil arbejdet med at udfærdige en policy være drevet primært af behov for at mobilisere politisk opbakning og få den til at fremstå spiselig for alle parter (Mosse 2007:648). Vi ser det i tilfældet „Handlingsplanen om sygefravær“, hvor til- og fravalg af de enkelte forslag bliver styret dels af overvejelser om, at de store interessenter på området skal kunne se deres egne aftryk i den endelige plan, dels af hensyntagen til, at handlingsplanen som helhed skal kunne betale sig. Den skal altså ikke koste flere penge at udføre, end den på sigt vil spare. Der er forskellige hensyn, som skal tages i en sådan proces, for at en policy fremstår legitim, og for at den er solidt forankret. Mosse beskriver policy som en smeltedigel for agendaer (Mosse 2005:35) og viser, hvordan en policys succesfulde vedtagelse afhænger netop af dens evne til at rumme forskelligartede formål. Ud fra denne optik ser vi i ovenstående, hvordan „Handlingsplanen om sygefravær“ bliver stedet, hvor departementschefens ambition om at arbejde evidensbaseret smedes sammen med Jyttes ensides forslag om at tilgodese kommunernes tilbagevendende efterspørgsel på at kunne henvise visse sygedagpengemodtagere til forskellige aktiviteter.

Det er her i selve formuleringen af policy, at vi finder den første brudflade mellem forskningsmiljøerne og politikudviklingen. Set fra et forskningsmæssigt synspunkt bliver ambitionen om at arbejde evidensbaseret sneget underligt ind ad sidedøren, hvor den burde have været det primære, når vi taler om evidensbasering. Set fra politikudviklingens ståsted er „Handlingsplanen om sygefravær“ og dens underforslag et stykke solidt udført håndværk. Handlingsplanen medierer og forener forskellige relevante og vigtige agendaer og bliver bredt vedtaget, hvorved den fremstår legitim set fra et demokratisk synspunkt og fornuftig set fra et samfundsøkonomisk synspunkt. Men som vi skal se, havde embedsværket ved at bevæge sig ind på evidensbaseret territorium bevæget sig langt uden for sit ekspertisefelt. Forsøget udviklede sig lynhurtigt til en kontroversiel affære, hvor embedsværk og forskningsmiljøerne tog gensidigt afstand fra hinanden. Ved at se på de punkter, hvor politikudviklingen og forskningen var i clinch, kan vi se, hvordan evidensparadigmet stiller nye krav til embedsværket, som ikke 
umiddelbart er forenelige med deres normale arbejdsgang og med det politiske miljø, de arbejder i.

\section{Anden brudflade: bureaukratisk versus akademisk tekstproduktion}

Omkring slutningen af november 2008 var jeg på udkig efter et stykke arbejdsmarkedspolitik, som kunne tjene som fokus for min forskning i policyimplementering. Min forskning var via ErhvervsPhD-ordningen samfinansieret af Beskæftigelsesministeriet og Aarhus Universitet, hvilket gav mig en sjælden adgang til de højeste niveauer i det danske embedsværk. Som følge heraf var jeg interesseret $i$ at se på et af de felter, der havde strategisk relevans for ministeriet. Et sådan område var sygefraværet. Da jeg læste mig igennem Beskæftigelsesm inisteriets nyligt vedtagne handlingsplan på udkig efter kommende indsatser, vakte forslag 32, „Forsøg med forebyggende og afklarende tilbud“ omgående min interesse. Titlen og undertitlen udtrykte henholdsvis en instruks (aktiv under sygemeldingen) og en hypotese (syge, der er aktive, kan lettere vende tilbage til arbejde). Selve brødteksten fremlagde hovedtrækkene i indsatsen, hvis implementering skulle foregå i en ekstremt kompleks kontekst (målgruppen kunne være i arbejde, gå til forskellig behandling, være under udredning, have gang i egne aktiviteter) og ville blive påvirket af mange forskellige aktørers samarbejde (de praktiserende læger, eventuelle arbejdsgivere, ,anden aktør“", sagsbehandlerne og den sygemeldte selv).

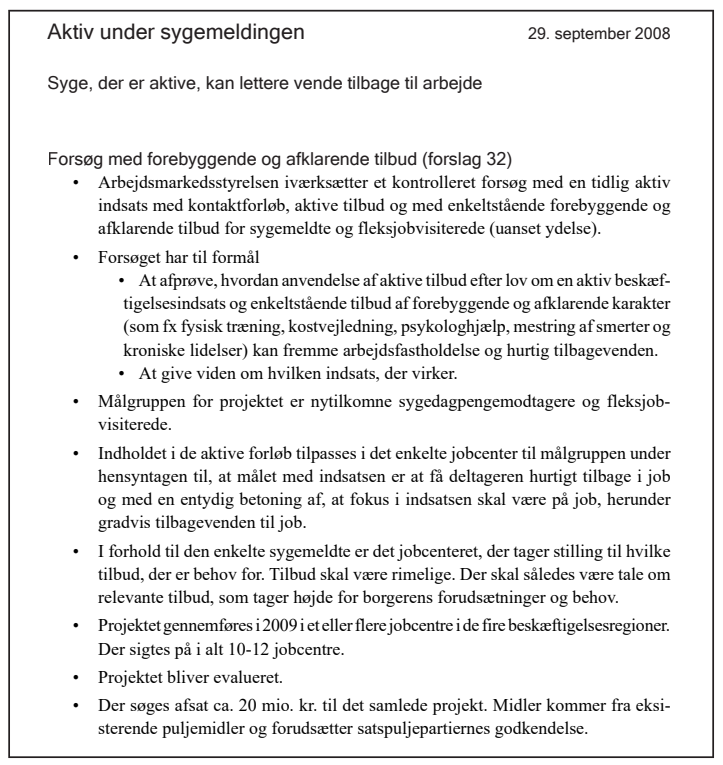

Konklusionspapir om handlingsplanen om sygefravær. Til brug for trepartsdrøftelser. (Beskæftigelsesministeriet 2008a:36). 
Forsøget ville ifølge første bullet være et kontrolleret forsøg, hvor de deltagende kommuner - således fremgik det af bullet fire og fem - havde en ret høj grad af metodefrihed til at bestemme indsatsens karakter. Denne paradoksale anvendelse af en af de mest rigide metodologier fra den medicinske verden koblet med metodefrihed skulle altså udføres i en ukontrollerbar kompleks social kontekst med reel tvungen deltagelse (det stod enhver frit at nægte at deltage, men i så fald ville man miste retten til sygedagpenge og dermed sit indkomstgrundlag). Eftersom forsøget altså i udgangspunktet forbrød sig imod de mest basale principper, som sådanne forsøg normalt baserer sig på - metodisk rigiditet samt fravær af tvang - udgjorde det for mig et uimodståeligt forskningsobjekt.

Forsøget var et led i en større tendens i Danmark i de år, hvor „,evidens“ begyndte at blive et nøgleord i dansk politik og offentlig administration. På det tidspunkt, i 2007-2008, så Sundhedsstyrelsen i alliance med en række større patientforeninger og det anerkendte Nordiske Cochrane Institut gerne, at sundhedssektoren i Danmark begyndte at arbejde mere evidensbaseret og gøre brug af „best practices“ (Sundhedsstyrelsen 2007). Samtidig vidste jeg fra anden sammenhæng, at nogle af de folk, som havde været tæt inde over udfærdigelsen af forsøget, havde været på studietur i USA planlagt af konsulentvirksomheden Rambøll Management, som samtidig tog sig af en pæn del af Beskæftigelsesministeriets evalueringer. Der havde været en del af disse studieture, hvor det „randomiserede kontrollerede forsøg" blev holdt frem som gylden standard for at vurdere offentlige interventioners effektivitet. Ifølge en af deltagerne havde omkring 200 topledere fra den offentlige sektor i Danmark på daværende tidspunkt deltaget i disse ture, og evidensbasering blev generelt anset for at være det nye paradigme for politikudvikling i det offentlige (se desuden Rieper \& Hansen 2007). Bortset fra disse kontekstuelle informationer, som jeg læste ind i det tyndt beskrevne „forslag 32“, var der ikke så meget at hente i handlingsplanen, og da jeg - af akademisk vane - bladrede frem til sidste side efter en referenceliste, fandt jeg ingen.

På daværende tidspunkt var jeg først ved at lære, at der - trods sammenfald i retorik og sprogbrug - er markant forskel på akademiske og bureaukratiske dokumenter (se også Riles 2006). I en akademisk skrivelse vil forfatterens navn tjene til at kommunikere ansvar for og ejerskab til data og analyse (fx Biagioli 2006). Med bureaukratiske skrivelser forholder det sig omvendt sådan, at deres forfattere hverken kan eller skal hævde ejerskab. Vejen til at blive et politisk dokument (en policy) er præcis konstitueret ved, at ejerskabet skridt for skridt overgives fra aktør til aktør - fx fra individuel embedsmand til kontor, fra kontor til styrelse, fra styrelse til ministerium, nogle gange fra ministerium til regering og ultimativt i tilfælde af lovgivning fra regering til Folketinget. På denne rejse 
bliver de enkelte dokumenter ikke blot destilleret for personlig involvering, de renses også for de konkrete henvisninger og argumentationskæder, der på tidligere stadier i dokumenternes liv har ligget til grund for deres påstande og normative udtalelser. Som Annelise Riles (2006) påpeger i sit studie af policyproduktion i FN: Det officielle bureaukratiske dokument er ikke optaget af at overbevise sin læser om soliditeten af en argumentation eller en konklusion, men om at fastslå, hvad man er blevet enige om. Hvor de indledende analyserapporter, som embedsværket udarbejdede i processen frem imod vedtagelsen af "Handlingsplanen om sygefravær“, var fulde af referencer til undersøgelser med relation til sygefraværet, var der ikke en eneste reference og ikke et eneste argument at finde i det politiske slutprodukt, som handlingsplanen var. Tilbage i november 2008, da jeg første gang stødte på handlingsplanen og forsøget, begyndte jeg derfor, med hjælp fra min forskningsassistent Rasmus Kolding, at lede efter de undersøgelser og den evidens, som indsatsen hævdede at bygge på.

Vi koncentrerede vores fokus på det kontrollerede forsøg samt på et forslag om at erstatte „lægeerklæring om uarbejdsdygtighed“ med en ,,mulighedserklæring“. Sidstnævnte forslag betød, at lægerne fremover ved sygdom ikke skulle beskrive begrænsningerne $\mathrm{i}$ en persons arbejdsevne, men i stedet for skulle beskrive de punkter, hvor vedkommende person - trods sygdom - fortsat ville kunne passe sit arbejde. I tilfældet „mulighedserklæring“ sporede vi begrebet til Storbritannien (her kaldet „fit note“) til Dame Carol Black. Black var på det tidspunkt den britiske regerings nationaldirektør for det tværgående organ „Health and Work“ og var i 2007 blevet anmodet af den britiske modpart til den danske beskæftigelsesminister (Secretary of State for Health and for Work and Pensions) om at stå i spidsen for ,det første review nogensinde af helbredet blandt den britiske befolkning i den arbejdsduelige alder" (Black 2008a, min oversættelse, NHV). I oktober 2007 havde hun udsendt et „call for evidence“, hvor hun efterspurgte svar på otte spørgsmål i relation til samspillet mellem helbred, sundhedssystemets tilbud og briternes arbejdsliv (op.cit.3). Den følgende indsendte „evidens““ blev analyseret og sammenfattet af Dame Carol Black. „Evidensen“ udgjorde en blanding af holdninger fremsat af interessenter, personlige beretninger fra sundhedspersonale, videnskabelig forskning og forslag fra tænketanke. I Blacks review „Working for a Healthier Tomorrow“ (Black 2008b) figurerede forslaget om at erstatte den eksisterende ,sick note“ med en „fit note“ som en ud af ti endelige anbefalinger (op.cit.17). Den nøgleudfordring, Black havde identificeret i sin evidensgennemgang, var, at den eksisterende ,sick note“ institutionaliserede „troen på, at det er upassende at gå på arbejde, medmindre man er 100 procent rask, og at det at gå på arbejde udgør en hindring for helbredelsen“" (Black 2008b: 16, min oversættelse, NHV). En „,fit note“, som fokuserede på muligheder frem for sygdom, skulle altså være en løsning på dette. 
Hvis en videnskabelig tekst og et policydokument umiddelbart kan minde om hinanden i deres brug af akademisk jargon og opbygning, bliver denne lighed ikke mindre, når policydokumentet hævder at være evidensbaseret. I Blacks rapporter smeltede dele af de to tekstlige genrer sammen: Det var på den ene side ikke den klassiske reference- og argumentationsfrie genre, som policydokumenter ellers udgør, men omvendt var der ingen systematisk brug af referencer til at understøtte de argumenter og antagelser, der blev fremsat. Black angav fx, at ,den eksisterende 'sick note' udgør en begrænsning“, og at ,,arbejde faktisk kan fremme helbredelse“ (Black 2008a: 46, mine oversættelser, NHV), men der var ingen referencer, som understøttede disse påstande. De sider, hvor Black opsummerede den indkomne evidens, der specifikt relaterede til „,sick note“ og genoptagelse af arbejde under sygdom (op.cit.13f.), efterlod indtrykket af, at den omtalte ,evidens“" mere præcist kunne karakteriseres som indtryk, antagelser og erfaringer, fremsat af blandt andet sundhedspersonale. Ikke desto mindre var det præcis disse sætninger, som muliggjorde, at den britiske regering i sit svar på Blacks rapport konkluderede, at ,[e]vidensen viser, at generelt betragtet er det godt for helbredet at gå på arbejde“ (UK Government 2008, min oversættelse, NHV).

Da vi var kommet så langt i vores evidenseftersøgning, kunne vi konstatere, at den danske interesse for sygefravær og især ideen om, at det var gavnligt at gå på arbejde trods sygdom, var del af en bredere tendens, men vi var stadig ikke kommet nærmere noget eksempel på den omtalte „evidens“, som beskæftigelsesministeren og arbejdsmarkedets parter blev ved med at omtale i medierne, når de skulle udtalte sig om handlingsplanen (se Madsen 2008). På et tidligere tidspunkt var jeg gået over i Arbejdsmarkedsstyrelsen og havde fundet den medarbejder, som var tovholder for det kontrollerede forsøg, som nu hed „Aktive - Hurtigere tilbage“. Hun havde ikke været tilstrækkeligt involveret $\mathrm{i}$ udviklingen af forsøget til at kunne fortælle mig om konkrete studier (det syntes i øvrigt at gøre sig gældende for alle involverede, se også Madsen 2008), men hun henviste mig til den række af analyserapporter, som handlingsplanen byggede på - altså den føromtalte analyse af sygefraværet, som embedsværket havde udarbejdet og bestilt i løbet af 2008 . Jeg vendte mig nu mod disse rapporter og begyndte at inspicere rapporternes henvisninger og litteraturlister.

Det viste sig hurtigt, at en central reference, som blev ved at dukke op, var en „hvidbog“ (en politisk bestilt forskningsgennemgang) om sygefravær, hvoraf det fremgik, at hvis man forholder sig inaktiv, hvis man har ryg- eller muskelsmerter, kan det i nogle tilfælde forværre lidelserne (NFA 2008). Det fremgik dog ikke heraf, at der omvendt var evidens for, at det at forholde sig aktiv i alle tilfælde af sygdom ville føre til hurtigere helbredelse, og intet indikerede, at hurtig genoptagelse af arbejdet i tilfælde af fx angst, stress eller depression ville føre til helbredelse. Alligevel blev forsøget „Aktive - Hurtigere tilbage“ 
promoveret som drevet af evidens. En af hovedtalerne på et opstartsseminar for forsøget i december 2008 udtalte fx, at „nu skal vi have aflivet myterne og fundere indsatsen [nedbringelsen af sygefravær] på videnskab", og en anden hovedtaler meddelte, at ,det er godt at komme tilbage på arbejdspladsen, hvis man har stress eller depression“. Ingen af de tilstedeværende repræsentanter for forsøgskommunerne satte spørgsmålstegn ved disse udsagn, til trods for at debatten om den manglende evidens på det tidspunkt allerede var begyndt at rase i medierne, hvor journalisterne, præcis som jeg, viste sig ude af stand til at finde den omtalte evidens eller en ekspert på området, som ville kendes ved den.

Hvis vi skal forstå, hvordan embedsmændene og de politikere, de rådgav, kunne blive ved med at insistere på evidensbaseringen - trods entydig kritik fra forskningsmiljøet - må vi forstå en af de helt fundamentale forskelle på videnskabelige tekster og policydokumenter: Policy-dokumentet adskiller sig fra den videnskabelige tekstproduktion derved, at det er et autoritativt beslutningspapir. Forud for offentliggørelsen af de endelige dokumenter har de været gennem mange omskrivninger og korrektionsprocesser. På hvert niveau af føromtalte „rensning“ for personligt engagement - altså ved hver oversendelse fra kontor til styrelse, styrelse til departement, departement til minister - er det de relevante embedsmænds ansvar at godkende og garantere for rigtigheden af de oplysninger, som sendes videre. Når vi altså når til vejs ende - ved vedtagelsen af den argumentfrie, referenceløse „Handlingsplanen om sygefravær“ - er det de rene ,fakta“, vi sidder tilbage med. At stille spørgsmålstegn ved oplysningerne i dokumentet er at stille spørgsmålstegn ved embedsværkets funktionalitet. Hvis der står, at det er evidensbaseret, må den enkelte embedsmand og politiker stole på, at det er det. Hvis embedsværket overhovedet skal kunne fungere og fremstå legitimt, kan den enkelte politiker og embedsmand ikke sidde og forholde sig kritisk tvivlende til de oplysninger og rapporter, de rekvirerer fra deres kolleger og underafdelinger. Det forholder sig omvendt i forskningsmiljøerne, hvor den kritiske granskning af fagfællers tekstproduktion er en kernekompetence. Dette misforhold peger frem imod yderligere to relaterede brudflader mellem evidensproduktion og policyproduktion, nemlig dels i forhold til den plads, debat og kritik indtager på de to ekspertisefelter, og dels i forhold til det, man kan kalde kernehåndværket: den politiske proces over for en videnskabelig metoderigiditet.

\section{Tredje brudflade: kritikkens rolle i forskning og politikudvikling}

At „Handlingsplanen om sygefravær“ og i særdeleshed „Aktive - Hurtigere tilbage" blev præsenteret som evidensbaserede, havde en signifikant og uventet 
implikation for policyudviklerne. Ved at trække på akademisk sprogbrug og portrættere indsatsen som videnskabelig påkaldte beskæftigelsesministeren og hans embedsmænd sig pressens og ikke mindst forskningsmiljøets granskende blik (for en lignende situation i UK, se Boden \& Epstein 2006:234). Det betød, at allerede inden forsøget gik i gang, var det under intensiv kritik fra både medier og forskere og fortsatte med at være det $\mathrm{i}$ hele sin løbetid, idet ingen på noget tidspunkt viste sig i stand til at opdrive den bemeldte evidens.

En professor med speciale i sygefravær, som i en årrække havde arbejdet i netop den forskningsinstitution (Det Nationale Forskningscenter for Arbejdsmiljø), som ministeriet vedblev at henvise til vedrørende evidens, havde endog skrevet og indgivet en analyserapport til Folketingets arbejdsmarkedsudvalg. Her havde han fremlagt en analyse, som viste, at ikke blot var det danske sygefravær ikke højt sammenlignet med de øvrige lande, man normalt målte sig i forhold til, og det var heller ikke steget hen over de seneste årtier. Desuden, fastslog han, var der ingen evidens, som underbyggede den planlagte indsats (Kristensen 2008). Med andre ord, med sin fagekspertise som indsats påpegede han, at hele grundlaget for „Handlingsplanen om sygefravær“ var misvisende (altså billedet af drastisk stigende udgifter til sygedagpenge og dramatisk stigning i antallet af sygemeldte). Det samme var den såkaldte evidensbasering. Alligevel blev hans og andres indlæg fra forskningsmiljøerne ignoreret, mens foldere, taler og notater, som uden at gøre brug af kildehenvisninger fastholdt, at indsatsen var evidensbaseret, ivrigt blev cirkuleret og citeret.

Jeg tillader mig at se bort fra den mulighed, at ministeren og hans embedsmænd bevidst manipulerede med fakta, idet mine data ikke underbygger en sådan konklusion (se dog Tynell 2014 for muligheden af dette). I stedet vil jeg fremhæve en anden forklarende omstændighed, som skal findes i forskellen på den rolle, som debat og kritik spiller $i$ henholdsvis et forskningsmiljø og et bureaukrati. Den følgende distinktion er noget groft tegnet, men vil bidrage med en anden ramme at forstå ovenstående praksis inden for. I forskningsmiljøerne begynder den faglige diskussion, når et argument ( $\mathrm{x}$ i form af en præsentation eller en artikel) er blevet fremlagt for fagfællerne. Man forventer, at argumentationskæden ses efter i sømmene, og selv om ingen glæder sig over at få udstillet fejl og mangler, er man „fair game“, når man lægger sine argumenter og konklusioner frem. I embedsværket forholder det sig omvendt sådan, at offentliggørelsen af et dokument (en handlingsplan eller en politik på et givent område) markerer, at diskussionen er ovre, og det, som ligger for, er arbejdet med at implementere den valgte kurs. På denne baggrund tog forskerne, som fremsatte kritik af handlingsplanens antagelser, grundigt fejl, hvis de troede, at yderligere input vedrørende enkelte forslag og vedrørende hele fundamentet ville være velkomne. I embedsværket blev deres 
indlæg opfattet som personligt motiverede og irrelevante - endog taktløse - indlæg, som ville (om overhovedet) have hørt til på et langt tidligere stadium i politikudviklingsprocessen. Omvendt, set fra forskningsmiljøets og den kritiske del af pressens perspektiv, blev den vedvarende mangel på lydhørhed over for de fagprofessionelle og deres granskning af evidensgrundlaget betragtet som vildledning og i værste fald datamanipulation. Dette leder mig frem til den fjerde brudflade mellem forskningsmiljøerne og policyudviklerne. Dette går nemlig til kernen af deres respektive håndværk, henholdsvis at håndtere og bedømme data versus at håndtere den politiske proces.

\section{Fjerde brudflade: håndværkets genstand - politisk proces versus data}

Nogle af de statistikker og konklusioner, som blev citeret i den analyserapport, der lå til grund for handlingsplanen (Arbejdsmarkedsstyrelsen 2008:27-28), synes at modsige hypotesen, som det kontrollerede forsøg var baseret på - altså, at de sygemeldte uanset diagnose ville nyde godt af ,aktivitet“. Et sted kunne man fx læse, at der er ,tegn på, at brugen af aktive tilbud og delvise raskmeldinger bør doseres nøje ud fra de konkrete diagnoser og deraf afledte behov" (Arbejdsmarkedsstyrelsen 2008:36), og i en fodnote kunne man læse, at „delvise raskmeldinger [kan] være uegnede for sygemeldte med tungere psykiske lidelser" (op.cit.28, n. 62). En konsulent, som havde været ansvarlig for udarbejdelsen af selvsamme rapport, fortalte mig, at han i sin forskningsgennemgang ikke var stødt på nogen undersøgelse, der støttede antagelsen om, at psykisk syge ville få det bedre, hvis de vendte hurtigt tilbage til arbejdspladsen. Om noget, sagde han, syntes nogle studier at indikere, at folk risikerede at få det værre, specielt hvis de vendte tilbage til samme stilling. Hertil kom offentliggørelsen af en kontroversiel artikel i Ugebrevet A4, hvor samtlige ledende forskere og eksperter på sygefraværsområdet (heraf flere fra Beskæftigelsesministeriet s eget forskningscenter - Det Nationale Forskningscenter for Arbejdsmiljø - samstemmigt nægtede kendskab til føromtalte evidensgrundlag (Madsen 2008). Særligt interessant i den sammenhæng var, at en af medforfatterne på en publikation, som embedsmændene igen og igen fremhævede i deres forsvar af det kontrollerede forsøg, specifikt sagde, at han anså, at forsøg på at få folk, som led af stress eller depression, til at vende tilbage til deres arbejdsplads uden den rette behandling, var dømt til at fejle (ibid.). Et halvt år senere deltog jeg i et møde internt i Arbejdsmarkedsstyrelsen mellem nogle embedsmænd og et eksternt konsulentbureau. Her blev spørgsmålet om „evidensen“ rejst igen omend i en anden kontekst. Embedsmændene ville citere „evidensen“ i en kampagne rettet 
mod blandt andre ,anden aktør" (altså de private virksomheder, som varetog indholdsdelen af beskæftigelsesindsatsen). En af konsulenterne afbrød deres diskussion:

Konsulent: Der er noget evidens på skelet- og muskelsygdomme, men det er der efter første føler ikke på det psykiske område. Der er ingen evidens, og jeg ville holde mig langt væk fra at igangsætte en undersøgelse.

Embedsmand: Men Peter Østergaard ${ }^{2}$ siger, at ...

Konsulent: Ja, han har nogle erfaringer, og dem skal vi nok kommunikere, men det er $i k k e$ forskning. Jeg ville være loren ved at igangsætte en undersøgelse, hvor resultatet kommer negativt tilbage.

Efter denne kontante udtalelse virkede de tilstedeværende embedsmænd oprigtigt forvirrede over den manglende „evidens" trods al den forudgående kritik fra forskerstanden og trods den omfattende debat i medierne, der havde stået på i mere end et halvt år. På det tidspunkt havde kritikken af forsøget udvidet sig til også at omfatte en stor diskussion, som ledte til flere samråd i Folketinget om, hvorvidt der overhovedet var juridisk hjemmel til at gennemføre forsøget (se Tynell 2014). Som i tilfældet med evidensen var der ingen fra det juridiske forskningsmiljø, som vurderede, at der var hjemmel til at gennemføre forsøget. Nogle mente endog, at det at fratage forsøgsdeltagerne deres ret til sygedagpenge, hvis de nægtede at deltage, var i strid med menneskerettighedskonventionerne (ibid.). Alligevel var troen på evidensbaseringen og på den juridiske legitimitet så forankret $\mathrm{i}$ Arbejdsmarkedsstyrelsen, at deres vicedirektør på et møde mellem kommunerne og styrelsen opsummerede den samlede kritik fra forskningsmiljøerne, som „lidt chikane og meget, meget politik“.

Vi kan læse disse eksempler på to måder: Vi kan fortolke det som et lærebogseksempel på policybaseret evidensfrembringelse (Boden \& Epstein 2006; House of Commons 2006), altså et eksempel på den model for forskningsanvendelse, som Weiss kalder „politisk“, og hvor man håndplukker den forskning og de oplysninger, som støtter ens argument, mens man ignorerer resten (Weiss 1979: 429). Ikke blot har embedsmændene udvalgt den eneste „ekspert“, som i embedsmændenes egen fortolkning og udlægning (og ikke nødvendigvis hans egen!) støtter deres vedholdende påstand om, at evidensgrundlaget findes, ud af et kor på adskillige forskere, som nægter, at den findes. De ignorerer også og forhindrer aktivt modstridende fortolkninger - den faktiske evidens - i at komme frem.

Men vi kan også, og stadig i overensstemmelse med fakta, fortolke situationen som én, hvor embedsmændene har dristet sig ind på et ekspertiseområde (den akademiske forskning), som ligger meget fjernt fra deres eget. De er kommet ud på dybt vand og holder fast $\mathrm{i}$ det, de kender og er bedst til, nemlig at navigere $\mathrm{i}$ den politiske proces: De embedsmænd, jeg traf, som var involveret $i$ at forberede 
og lede det kontrollerede forsøg, havde, (som fremgår af eksemplet ovenfor) absolut ingen faglige forudsætninger for at sortere i, hvad der kvalificerede sig som evidens (fx fagfællebedømte, offentliggjorte forskningsresultater), og hvad der ikke gjorde (fx en privat praktiserende psykiaters kliniske erfaringer). Hvad de forstod sig på og havde rig erfaring med, var derimod at håndtere en kompleks proces, hvor mange forskellige interessenter fremsatte modstridende påstande. På sæt og vis behandlede de kritikken fra forskningsmiljøerne (både feltet omkring sygefraværsforskning og det juridiske felt) præcis, som de ville have behandlet kritik fra KL eller DI eller oppositionspartierne - nemlig som politisk motiverede partsindlæg. Embedsværket stod måbende over for, hvad de anså for at være en horde af taktløse, politiserende forskere. Omvendt stod forskningsmiljøet måbende over for en aktør (embedsværket), som var trådt ind på deres arena (evidensproduktionen og -håndteringen), men som samtidig overhørte deres faglige indlæg og som havde en uacceptabel og lemfældig omgang med data.

\section{Konklusion}

Ved at bevæge sig ind på det evidensbaserede felt havde policyudviklerne fjernet sig fra deres ekspertisefelt. Det kontrollerede forsøg „Aktive - Hurtigere tilbage“, som var flagskib i forsøget på at arbejde på en ny og ,evidensbaseret“ måde, udviklede sig omgående til en højst kontroversiel sag, hvor det blev tydeligt, at politikudvikling og evidensudvikling er svært forenelige.

Jeg har i denne artikel argumenteret for, at der er en række fundamentale forskelle på de to håndværk: formålet med den skriftlige produktion (at fremlægge argumentation versus at præsentere konsensus blandt de involverede parter og udstikke en vej fremad), den rolle, kritik og debat indtager (at kvalitetssikre argumenter og udvikle hypoteser versus at være tidlige partsindlæg eller forsøg på politisering), samt hvad genstanden for håndværket er (at sikre valide data versus at forvalte den politiske proces). Disse udfordringer skal ses i lyset af den indledende omstændighed, at de fleste policies er født ud af politiske forhandlinger - hvis ikke mellem politikere, så mellem de store berørte interessentgrupper. Som policy betragtet var „Handlingsplanen om sygefravær“ derfor ikke blot et svar på en bestemt problematik (sygefraværet). Den var en smeltedigel for en række forskellige dagsordener: Den skulle redde de offentlige budgetter, den skulle sikre arbejdsudbuddet, den skulle krone departementschefens ambition om at arbejde evidensbaseret, den skulle sikre bred opbakning til regeringens politik på tværs af interessenterne på arbejdsmarkedsområdet, og endelig skulle den bidrage til de kommunalt ansatte sagsbehandleres følelse af at foretage sig noget meningsfuldt. 
På den baggrund kan vi se, at forsøget „Aktive - Hurtigere tilbage“ og „Handlingsplanen om sygefravær"i mindre grad var den bedst mulige vej til at reducere sygefraværet, men snarere det bedst mulige fundament, hvorpå regeringen kunne mobilisere støtte til sin ambition om at nedbringe sygefraværet. Som sådan betragtet var handlingsplanen i embedsværkets egen optik et solidt udført stykke håndværk. Eller med Leas ord simpelthen bare ,almindelig god ministerbetjening“. Men det var de selvsamme klassiske embedsmandsdyder, som gjorde „Handlingsplanen om sygefravær“ til en succes, der kunne vedtages uden ændringer og med bred opbakning, som udgjorde den største udfordring i forhold til dens mulighed for at lykkes som evidensbaseret policyudvikling.

Hvad jeg håber at have kommunikeret her, er en ramme, inden for hvilken vi kan forstå, hvordan det går til, at evidensbaseret politikudvikling langt hen ad vejen forbliver et ideal trods vedholdende vilje og pres fra regeringer og deres administrationer. Den forbliver et ideal, fordi der i ambitionen om at udvikle politik på baggrund af evidens ligger en antagelse om en uproblematisk forening af de to discipliner - forskningen og politikudviklingen. Jeg har her vist, hvordan de er konstitueret forskelligt, og jeg har fremhævet fire brudflader mellem disciplinerne, som den evidensbaserede politikudvikling må udspille sig langs.

Søgeord: evidensbaseret politik, embedsværket, policy, bureaukrati, Danmark

\section{Noter}

1. Med Whittys ord: ,a site of mutual misunderstanding“ (Whitty 2006:160).

2. En privatpraktiserende psykiater, som turnerede med Arbejdsmarkedsstyrelsen i relation til forsøget. Jeg har tilladt mig at ændre navnet, idet psykiateren blev taget til indtægt for en del udtalelser i embedsværkets favør, som det nok er meget tvivlsomt, han selv ville bakke op.

\footnotetext{
Litteratur

Arbejdsmarkedsstyrelsen

$2008 \quad$ Viden om sygefravær. København: Mploy.

Bason, Christian

2010 Leading Public Sector Innovation. Co-creating for a Better Society. Bristol \& Portland: Policy Press.

Beskæftigelsesministeriet

2008a Konklusionspapir om handlingsplan om sygefravær. 29. september. http://

www.ac.dk/media/31379/aftaletekst-sygefravaer.pdf

2008b Analyse af sygefraværet. København: Beskæftigelsesministeriet.
} 
Biagioli, Mario

2006 Documents of Documents: Scientists' Names and Scientific Claims. In: A. Riles (eds): Documents. Artifacts of Modern Knowledge. Pp. 127-57. Ann Arbor: The University of Michigan Press.

Black, Dame Carol

2008a Dame Carol Black's Review of the Health of Britain's Working age Population. Summary of evidence submitted. Publiceret af the Cross-governmental Health, Work and Well-being Programme. 17. marts. Norwich: The Stationery Office.

2008b Dame Carol Black's Review of the Health of Britain's Working Age Population. Working for a Healthier Tomorrow. Publiceret af the Cross-governmental Health, Work and Well-being Programme. 17. marts. Norwich: The Stationery Office.

Boden, Rebecca \& Debbie Epstein

2006 Managing the Research Imagination? Globalisation and Research in Higher Education. Globalisation, Societies and Education 4(2):223-36.

Cartwright, Nancy, Andrew Goldfinch \& Jeremy Howick

2009 Evidence-based Policy: Where is our Theory of Evidence? In Journal of Children's Services 4(4):6-14.

Elliott, Heather \& Jennie Popay

$2000 \quad$ How are Policy Makers Using Evidence? Models of Research Utilization and Local NHS Policy Making. Journal of Epidemiology and Community Health 54(6):461-68.

Ferguson, James

1994 [1990] The Anti-politics Machine. "Development", Depoliticization, and Bureaucratic Power in Lesotho. Minneapolis, MN: University of Minnesota Press.

Hartley, Jean

2005 Innovation in Governance and Public Services: Past and Present. Public Money \& Management 25(1):27-34.

House of Commons (Science and Technology Committee)

2006 Scientific Advice, Risk and Evidence Based Policy Making. Vol. 1. London: The Stationery Office Limited.

Kristensen, Tage Sønderskov

2008 Arbejdsmarkedsudvalget 2008-09. AMU alm. delbilag 54, offentligt. 22. december. http://www.ft.dk/samling/20081/almdel/amu/bilag/54/628389.pdf .

Li, Tania Murray

2007 The Will to Improve. Governmentality, Development, and the Practice of Politics. Durham \& London: Duke University Press.

Madsen, Tanja Nyrup

2008 Syge presses i arbejde på forkert grundlag. Ugebrevet A4. 13. oktober.

Miller, Peter \& Nikolas Rose

2008 Governing the Present. Administering Economic, Social and Personal Life. Cambridge: Polity Press.

Mosse, David

2005 Cultivating Development. An Ethnography of Aid Policy and Practice. London \& New York: Pluto Press. 

and Practice. In: A.C. Jimenez (ed.): The Anthropology of Organisations. Pp. 451-83. Surrey \& Burlington: Ashgate.

Mulgan, Geoff

2009 The Art of Public Strategy. Mobilizing Power and Knowledge for the Common Good. New York: Oxford University Press.

NFA, Det Nationale Forskningscenter for Arbejdsmiljø.

2008 Hvidbog om sygefravær og tilbagevenden til arbejde ved muskel- og skeletbesvær. Årsager og handlemuligheder. København: Det Nationale Forskningscenter for Arbejdsmiljø.

Nilsson, Måns et al.

2008 The Use and Non-use of Policy Appraisal Tool in Public Policy Manking: An Analysis of Three European Countries and the European Union. Policy Sciences 41(4):335-55.

Rambøll

2010 Evaluering: Aktive - Hurtigere tilbage. Udarbejdet for Arbejdsmarkedsstyrelsen. København: Rambøll.

Regeringen

2008 Sygefravær - en fælles udfordring. Regeringens handlingsplan for at nedbringe sygefraværet. København: Beskæftigelsesministeriet.

Rieper, Olaf \& Hanne Foss Hansen

2007 Metodedebatten om evidens. København: AKF Forlaget.

Riles, Annelise

2006 [Deadlines]: Removing the Brackets on Politics in Bureaucratic and Anthropological Analysis. In: A. Riles: Documents. Artifacts of Modern Knowledge. Pp. 71-94. Ann Arbor: The University of Michigan Press.

Rod, Morten Hulvej

$2010 \quad$ Forebyggelsens momenter. En antropologisk analyse af evidens of etik i tiltag rettet mod unges brug af alkohol. Ph.d.-rækken nr. 59. København: Institut for Antropologi. Københavns Universitet.

Sundhedsstyrelsen

2007 Evidens i forebyggelsen. København: Sundhedsstyrelsen. http:// sundhedsstyrelsen.dk/ /media/2005D73969F948B9B247D43AB7BD29D7.ashx

Tynell, Jesper

2014 Mørkelygten. København: Samfundslitteratur.

UK Government

2008 Improving Health and Work: Changing Lives. The Government's Response to Dame Carol Black's Review of the Health of Britain's Working-age Population. Norwich: The Stationery Office

Vohnsen, Nina Holm

2011 Absurdity and the Sensible Decision. Implementation of Danish Labour Market Absurdity and the Sensible Decision. Implementation of Danish Labour Market
Policy. Ph.d.-afhandling. Institut for Kultur og Samfund, Aarhus Universitet.

2013 Evidence-based Policy: Some Pitfalls in the Meeting of Scientific Research and Politics. Anthropology Today 29(5):3-5. 
Weiss, Carol H

1979 The Many Meanings of Research Utilization. Public Administration Review 39(5): 426-31.

Whitty, Geoff 2006

Education(al) Research and Education Policy Making: Is Conflict Inevitable?

British Educational Research Journal 32(2):159-76. 